\title{
Efek konsumsi yogurt terhadap glukosa darah puasa pada penyandang diabetes melitus tipe 2
}

\author{
Farah Nuriannisa ${ }^{1,2}$, Nyoman Kertia $^{3}$, Lily Arsanti Lestari ${ }^{*}$
}

\begin{abstract}
Background: Generally, patients with type 2 diabetes mellitus (T2D) have dysbiosis condition. Dysbiosis can increase oxidative stress that leads to hyperglycemia. Previous researches showed that yogurt consumption can reduce blood glucose in T2D, so it can be used as an alternative healthy snack for T2D patients.

Objectives: To investigate the effects of probiotic and conventional yogurt with dosage 100ml/day on fasting blood glucose (FBG) in T2D patients

Methods: Randomized controlled trial, double blind with pre-post group design. The 30 T2D patients from 3 publics health centre in Yogyakarta, were assigned to two groups. Each group, either control or intervention group, received $100 \mathrm{ml} / \mathrm{d}$ of yogurt for 4 weeks. FBG samples was assessed before and after intervention period

Results: FBG significantly decreased in both group, which was $-27 \mathrm{mg} / \mathrm{dL}$ in control group (p<0.05) and $-19 \mathrm{mg} / \mathrm{dL}$ in intervention group $(p<0.05)$. No significant difference in FBG change between intervention and control group, but control group has greater reduction in FBG compared to intervention group.
\end{abstract}

Conclusion: Conventional yogurt has no significant difference effect in FBG change compared to probiotic yogurt.

Keywords : Type 2 diabetes mellitus; fasting blood glucose; conventional yogurt; probiotic yogurt

\section{ABSTRAK}

Latar Belakang : Secara umum, penyandang diabetes mellitus tipe 2 (DMT2) akan mengalami kondisi disbiosis yang dapat meningkatkan stress oksidatif tubuh sehingga memperparah kondisi hiperglikemia. Pemberian yogurt dapat memperbaiki kondisi hiperglikemia sehingga dapat dijadikan salah satu alternatif snack untuk penyandang DMT2.

Tujuan : Untuk meneliti efek pemberian yogurt probiotik dan yogurt konvensional dengan dosis $100 \mathrm{ml} / \mathrm{hari}$ terhadap nilai glukosa darah puasa (GDP) pada penyandang DMT2.

Metode : Desain randomized controlled trial dengan pre-post test group design. Subyek penelitian ini adalah 30 orang penyandang DMT2 yang berasal dari tiga wilayah kerja Puskesmas di Kota Yogyakarta. Pemberian yogurt dilakukan selama empat minggu dengan dosis $100 \mathrm{ml} / \mathrm{hari}$. Nilai GDP diukur sebelum dan setelah masa intervensi dilakukan.

Hasil : Berdasarkan hasil penelitian ini, kedua kelompok mengalami penurunan nilai GDP yang signifikan, yaitu sebesar -27 $m g / d L$ pada kelompok kontrol $(p<0,05)$ dan $-19 \mathrm{mg} / \mathrm{dL}(\mathrm{p}<0,05)$ pada kelompok perlakuan. Tidak terdapat perbedaan yang signifikan pada nilai selisih GDP antara kedua kelompok, namun penurunan nilai GDP pada kelompok kontrol lebih besar dibandingkan pada kelompok perlakuan.

Simpulan : Yogurt konvensional tidak memiliki perbedaan efek yang signifikan terhadap perubahan nilai GDP dibandingkan dengan yogurt probiotik.

Kata Kunci : diabetes mellitus tipe 2; glukosa darah puasa; yogurt konvensional; yogurt probiotik

\section{PENDAHULUAN}

Diabetes mellitus tipe 2 merupakan suatu gangguan metabolisme yang disebabkan oleh kerusakan sel $\beta$ pankreas sehingga muncul kondisi resistensi insulin dan peningkatan glukosa dalam darah (hiperglikemia). Penyakit diabetes mellitus tipe 2 menjadi salah satu dari sepuluh penyebab kematian utama akibat penyakit tidak menular di Indonesia. Tingginya angka kejadian diabetes mellitus mengindikasikan adanya peningkatan risiko angka komplikasi akibat diabetes, seperti komplikasi mikro-makrovaskuler, yang diakibatkan oleh kondisi hiperglikemia. ${ }^{1}$

Pada kondisi diabetes mellitus, terjadi ketidakseimbangan bakteri dalam usus (disbiosis) yang juga berkaitan dengan kondisi resistensi insulin. Kondisi resistensi insulin dan hiperglikemia pada penyandang diabetes mellitus dapat menyebabkan terjadinya

\footnotetext{
${ }^{1}$ Program Studi Gizi, Fakultas Kesehatan, Universitas Nahdlatul Ulama. Jl. Raya Jemursari 51-57 Surabaya, Jawa Timur, Indonesia

${ }^{2}$ Program Studi Ilmu Kesehatan Masyarakat, Fakultas Kedokteran, Kesehatan Masyarakat, dan Keperawatan, Universitas Gadjah Mada. Jl. Farmako Sekip Utara, Sleman, DI Yogyakarta 55281, Indonesia

${ }^{3}$ Departemen Ilmu Penyakit Dalam, RSUP Dr. Sardjito-Fakultas Kedokteran, Kesehatan Masyarakat, dan Keperawatan, Universitas Gadjah Mada. Jl. Farmako Sekip Utara, Sleman, DI Yogyakarta 55281, Indonesia

${ }^{4}$ Departemen Gizi Kesehatan, Fakultas Kedokteran, Kesehatan Masyarakat, dan Keperawatan Universitas Gadjah Mada. Jl. Farmako Sekip Utara, Sleman, DI Yogyakarta 55281, Indonesia

*Korespondensi : E-mail: santi_wap@yahoo.com; lily_al@ugm.ac.id, telp/fax: +6274-547775
} 
ketidakseimbangan antara nitric oxide (NO) dan reactive oxygen species (ROS), dimana terjadi peningkatan ROS dalam tubuh, yang berujung pada peningkatan sekresi biomarker inflamasi, seperti interleukin-6 (IL-6) dan nuclear factor- $k B$ (nf-kB) sehingga menyebabkan munculnya lesi-lesi yang menyumbat pembuluh darah., ${ }^{2,3}$ Oleh karena itu, dibutuhkan upaya sekunder untuk mencegah komplikasi akibat hiperglikemia tersebut. Salah satunya adalah dengan pemberian yogurt.

Yogurt merupakan produk hasil fermentasi susu menggunakan bakteri asam laktat Lactobacillus bulgaricus dan Streptococcus thermophilus. Konsumsi yogurt pada penyandang diabetes mellitus tipe 2 dapat membantu meningkatkan absorbsi dan utilisasi mineral, seperti zink, zat besi, dan kalsium, yang berguna dalam proses homeostasis melalui peningkatan produksi casein phosphopeptides (CPPs). Penambahan bakteri probiotik, seperti Bifidobacterium lactis dan Lactobacillus acidophilus, dapat meningkatkan efek kesehatan dalam yogurt, seperti memperbaiki profil glukosa darah dengan meningkatkan bakteri gram positif pada usus, misalnya jenis Lactobacillus dan Bifidobacterium, sehingga dapat merangsang produksi insulinotropic polypeptides dan glucagon-like peptide-1 yang berfungsi untuk meningkatkan uptake glukosa. ${ }^{4}$ Selain itu, beberapa strain bakteri, seperti bakteri Lactobacillus acidophilus dan Lactobacillus casei dapat berperan sebagai antioksidan sehingga dapat menurunkan kondisi stress oksidatif dalam tubuh. ${ }^{5}$

Berdasarkan literature review di atas, yogurt probiotik memiliki efek kesehatan yang lebih banyak, sehingga pemberian yogurt probiotik diyakini mampu menurunkan nilai glukosa darah puasa lebih banyak pada penyandang DMT2 dibandingkan dengan pemberian yogurt konvensional. Penelitian ini mempertimbangkan karakteristik masyarakat Indonesia yang masih rendah dalam mengonsumsi susu dan olahannya, sehingga produk yogurt konvensional (dengan bakteri starter) dan produk yogurt probiotik (dengan bakteri Bifidobacterium lactis dan Lactobacillus acidophilus) diberikan dengan dosis $100 \mathrm{ml} /$ hari (jumlah bakteri $>10^{6} \mathrm{CFU} / \mathrm{ml}$ ) kepada penyandang DMT2.

\section{BAHAN DAN METODE}

Penelitian ini menggunakan desain double blind randomized controlled trial dengan pre-post test group design. Penelitian ini dilakukan selama empat minggu masa intervensi, dengan total sampel sebanyak 34 orang penyandang diabetes mellitus 2 yang dikumpulkan dari Puskesmas Gondokusuman 1, Puskesmas Umbulharjo 2, dan Puskesmas Tegalrejo Yogyakarta yang kemudian dialokasikan secara random dalam dua kelompok. Ketiga Puskesmas tersebut dipilih karena ketiga Puskesmas tersebut memiliki prevalensi penyandang diabetes mellitus tipe 2 terbanyak di kota Yogyakarta berdasarkan data dari Dinas Kesehatan Kota Yogyakarta. Selain itu, lokasi Puskesmas juga dipertimbangkan agar mobilisasi dan distribusi produk tidak terlalu berjauhan antar wilayah. Subjek dalam kelompok perlakuan maupun kelompok intervensi masing-masing berjumlah 17 orang dengan proporsi usia dan jenis kelamin terlampir pada Tabel 2. Dari 34 subyek tersebut, sebanyak 4 orang mengalami drop out, sehingga jumlah subyek yang menyelesaikan masa intervensi sebanyak 30 orang.

Yogurt yang digunakan dalam penelitian ini diproduksi oleh CV. Violla Food Sleman, dengan formulasi dari peneliti. Formulasi yang digunakan pada kedua produk sama dari segi komposisi dan jumlah bahan, namun jenis bakteri yang digunakan berbeda. Produk yogurt yang diberikan kepada subyek juga memiliki sifat organoleptik yang serupa, baik dari aroma, warna, dan rasa. Kultur bakteri didapat dari Laboratorium Teknologi Pengolahan Susu dan Telur, Fakultas Peternakan, Universitas Gadjah Mada dan CHR-Hansen Jakarta. Pada yogurt konvensional, bakteri yang digunakan hanya kultur starter bakteri asam laktat (BAL) L. bulgaricus FNCC 0041 dan St. thermophilus FNCC 0040, sedangkan yogurt probiotik mengandung kedua kultur tersebut dan ditambahkan dengan $L$. acidophilus LA-5 dan Bifidobacterium lactis BB-12. Jumlah bakteri yang digunakan pada yogurt dalam penelitian ini tercantum dalam tabel 1 .

\section{Tabel 1. Jumlah Bakteri dalam Yogurt}

\begin{tabular}{lcc}
\hline & \multicolumn{2}{c}{ Jumlah Bakteri (CFU/ml) } \\
\cline { 2 - 3 } & Konvensional & Probiotik \\
\hline Bakteri starter asam laktat & $3,4 \times 10^{7}$ & $1,7 \times 10^{8}$ \\
L. bulgaricus FNCC 0041 & & \\
$\begin{array}{l}\text { St. thermophilus } \text { FNCC 0040 } \\
\text { Bakteri Probiotik }\end{array}$ & & $4,9 \times 10^{6}$ \\
L. acidophilus LA-5 & - & \\
Bifidobacterium lactis BB-12 & & \\
\hline
\end{tabular}

Kriteria inklusi meliputi penyandang DMT2 berusia 30-65 tahun, mengonsumsi metformin dan/atau sullfonilurea, tidak mengonsumsi antibiotik sebulan sebelum penelitian, memiliki refrigerator, bersedia mengikuti penelitian ini dengan sukarela mengisi dan menyerahkan informed consent yang disediakan peneliti, dan berdomisili di kota Yogyakarta. Kriteria eksklusi meliputi hamil dan/atau menyusui, intoleransi laktosa, komplikasi berdasarkan diagnosis dokter (kecuali hipertensi dan/atau dislipidemia).

Pemberian yogurt dilakukan selama empat minggu, dimana kelompok kontrol mendapatkan yogurt konvensional dan kelompok perlakuan mendapatkan yogurt probiotik. Nilai glukosa darah puasa diuji sebelum dan setelah intervensi dengan metode Hexokinase (Glucose-6-phosphate dehydrogenase atau G-6-PDH). Pengujian nilai glukosa darah puasa dipilih peneliti karena nilai glukosa darah puasa tidak 
dipengaruhi oleh jumlah dan jenis makanan dan/atau minuman yang dikonsumsi subyek. Proses pengambilan sampel darah dilakukan pada subyek sebanyak $3 \mathrm{ml}$ melalui pembuluh darah di lengan subyek. Pengambilan sampel dilakukan oleh tenaga terlatih dari Laboratorium Klinik Hi-Lab Yogyakarta Hasil penelitian akan diuji statistik menggunakan program STATA 12.0. Penelitian ini telah disetujui dan dinilai layak secara etik dari Komisi Etik Fakultas Kedokteran, Kesehatan Masyarakat, dan Keperawatan Universitas Gadjah Mada dengan nomor referensi : KE/FK/0251/EC/2018.

\section{HASIL}

Berikut adalah karakteristik subyek penelitian :

Tabel 2. Karakteristik Subyek Penelitian

\begin{tabular}{|c|c|c|c|}
\hline & \multicolumn{2}{|c|}{ Kelompok Perlakuan } & \multirow[t]{2}{*}{ p-value } \\
\hline & Kontrol & Perlakuan & \\
\hline Usia (tahun) & $53(8)$ & $57(9)$ & $0,211^{\mathrm{a}}$ \\
\hline \multicolumn{4}{|l|}{ Jenis kelamin } \\
\hline Pria & $4(26,67)$ & $5(33,33)$ & \multirow{2}{*}{$0,500^{\mathrm{b}}$} \\
\hline Wanita & $11(73,33)$ & $10(66,67)$ & \\
\hline \multicolumn{4}{|l|}{ Merokok } \\
\hline Ya & $0(0)$ & $3(20,00)$ & \multirow{2}{*}{$0,112^{\mathrm{b}}$} \\
\hline Tidak & $15(100)$ & $12(80,00)$ & \\
\hline \multicolumn{4}{|l|}{ Metformin } \\
\hline Ya & $13(86,67)$ & $13(86,67)$ & \multirow{2}{*}{$0,701^{\mathrm{b}}$} \\
\hline Tidak & $2(13,33)$ & $2(13,33)$ & \\
\hline \multicolumn{4}{|l|}{ Sulfonilurea } \\
\hline Ya & $8(53,33)$ & $10(66,67)$ & \multirow{2}{*}{$0,456^{\mathrm{c}}$} \\
\hline Tidak & $7(46,67)$ & $5(33,33)$ & \\
\hline Lama DMT2 (bulan) & $48(36)$ & $24(60)$ & $0,816^{\mathrm{a}}$ \\
\hline IMT $\left(\mathrm{kg} / \mathrm{m}^{2}\right)$ & $27,92 \pm 3,19$ & $27,94 \pm 4,74$ & $0,989^{d}$ \\
\hline \multicolumn{4}{|l|}{ Asupan } \\
\hline Energi (kkal) & $1044,78 \pm 284,90$ & $1049,84 \pm 308,42$ & $0,963^{\mathrm{d}}$ \\
\hline Protein $(\mathrm{g})$ & $29,2(12,15)$ & $29,95(23,65)$ & $0,648^{a}$ \\
\hline Lemak $(\mathrm{g})$ & $34,9(14,55)$ & $31,9(20,25)$ & $0,548^{\mathrm{a}}$ \\
\hline Karbohidrat (g) & $150,81 \pm 43,94$ & $148,29 \pm 49,39$ & $0,884^{\mathrm{d}}$ \\
\hline Serat $(\mathrm{g})$ & $6,75(3,15)$ & $8,05(8,15)$ & $0,788^{a}$ \\
\hline Sukrosa $(\mathrm{g})$ & $5,4(7,95)$ & $7,95(8,5)$ & $0,419^{\mathrm{a}}$ \\
\hline
\end{tabular}

Tabel 3. Kepatuhan Asupan Yogurt Subyek

\begin{tabular}{llll}
\hline & \multicolumn{2}{c}{ Kelompok } & P-value \\
\cline { 2 - 3 } & \multicolumn{1}{c}{ Kontrol } & Perlakuan & \\
\hline Kategori Asupan Yogurt (n $(\%))$ & $14(93,33)$ & $14(93,33)$ & $0,759^{\mathrm{b}}$ \\
Baik $(\geq 80 \%)$ & $1(6,67)$ & $1(6,67)$ & \\
Kurang $(<80 \%)$ & &
\end{tabular}

Keterangan : ${ }^{\mathrm{b}}=$ Fisher's exact $(\mathrm{n}(\%))$

Dari Tabel 2, tidak ada perbedaan yang signifikan pada karakteristik subyek kedua kelompok. Hal ini menandakan karakteristik kedua kelompok matching.

Kepatuhan subyek dalam mengonsumsi yogurt tergolong baik, yaitu sebesar 93,3\% dan tidak ada perbedaan signifikan pada kedua kelompok (Tabel 3). Pada Tabel 4, hasil uji Mann Whitney pada glukosa darah puasa menunjukkan bahwa tidak ada perbedaan yang signifikan antara pretest, posttest, dan selisih nilai glukosa darah puasa pada kedua kelompok, sedangkan dari hasil uji Wilcoxon ditemukan bahwa terdapat perbedaan yang signifikan sebelum dan setelah mendapatkan intervensi pada masing-masing kelompok (Tabel 4).
Tabel 4. Nilai GDP Subyek

\begin{tabular}{|c|c|c|c|}
\hline & \multicolumn{2}{|c|}{ Kelompok } & \multirow{2}{*}{$p$-value } \\
\hline & Kontrol & Perlakuan & \\
\hline \multicolumn{4}{|l|}{ Glukosa } \\
\hline $\begin{array}{l}\text { Darah Puasa } \\
(\mathrm{mg} / \mathrm{dL})\end{array}$ & $163(81)$ & $143(63)$ & $0,771^{\mathrm{a}}$ \\
\hline Pre-test & $111(51)$ & $122(49)$ & $0,443^{\mathrm{a}}$ \\
\hline Post test & $-27(53)$ & $-19(41)$ & $0,590^{\mathrm{a}}$ \\
\hline$\Delta$ & $0,007^{\mathrm{b} *}$ & $0,015^{\mathrm{b} *}$ & \\
\hline $\mathrm{p}$-value & & & \\
\hline
\end{tabular}




\section{PEMBAHASAN}

Penyandang diabetes mellitus tipe 2 umumnya akan mengalami gangguan keseimbangan mikrobiota dalam organ pencernaannya (disbiosis), dimana terjadi peningkatan bakteri patogen yang dapat mensekresikan lipopolisakarida (LPS). LPS ini dapat menyebabkan peningkatan inflammatory marker yang berhubungan dengan komplikasi vaskuler. Salah satu upaya yang dapat dilakukan untuk menurunkan bakteri patogen tersebut adalah dengan memperbaiki keseimbangan mikrobiota. Salah satunya dengan cara mengonsumsi produk yogurt.

Yogurt yang digunakan dalam penelitian ini mengandung bakteri asam laktat sebanyak $3,4 \times 10^{7}$ $\mathrm{CFU} / \mathrm{ml}$ untuk yogurt konvensional dan $1,7 \times 10^{8} \mathrm{CFU} / \mathrm{ml}$ serta $4,9 \times 10^{6} \mathrm{CFU} / \mathrm{ml}$ Bifidobacterium untuk yogurt probiotik. Jumlah bakteri asam laktat yang direkomendasikan dalam yogurt untuk memberikan efek kesehatan adalah sebesar $10^{6}-10^{7} \mathrm{CFU} / \mathrm{ml}$, sedangkan jumlah bakteri Bifidobacterium yang direkomendasikan adalah sebesar $>10^{6} \mathrm{CFU} / \mathrm{ml}$. Untuk menghasilkan efek kesehatan yang optimal, dosis pemberian yogurt dianjurkan sebanyak $100 \mathrm{ml} /$ hari. $^{7}$ Berdasarkan hal tersebut, jumlah bakteri dalam yogurt yang digunakan dalam penelitian ini sudah sesuai dan dapat berefek bagi kesehatan.

Penurunan nilai glukosa darah puasa yang terjadi pada kedua kelompok dapat disebabkan oleh adanya peningkatan bakteri gram positif yang berasal dari konsumsi yogurt yang diberikan. Peningkatan bakteri gram positif dapat membantu menurunkan jumlah bakteri gram negatif, sehingga jumlah LPS dan inflammatory marker juga berkurang. ${ }^{8}$ Selain itu, bakteri St. thermophilus juga memiliki kemampuan biosintesis asam folat dan gamma $(\gamma)$-aminobutiryc acid (GABA) yang berperan dalam proses regenerasi dan replikasi sel, sehingga kerusakan sel akibat stress oksidatif dapat diperbaiki. ${ }^{9}$ Kultur starter yang digunakan juga dapat mensekresi eksopolisakarida (EPS) yang berfungsi untuk meregenerasi sel-sel epitel saluran cerna sehingga proses absorbsi makanan menjadi lebih baik. ${ }^{10}$

Dalam penelitian ini, penurunan nilai glukosa darah puasa lebih besar terjadi pada kelompok kontrol dibandingkan dengan kelompok perlakuan $(p=0,590)$. Hal ini dapat terjadi karena yogurt probiotik yang diterima oleh kelompok perlakuan mengandung bakteri jenis Bifidobacterium, dimana Bifidobacterium merupakan bakteri probiotik jenis anaerob yang sensitif terhadap oksigen, suhu, dan $\mathrm{pH}$. Penurunan jumlah bakteri Bifidobacterium sangat mungkin terjadi selama penyimpanan karena kemasan cup yang digunakan masih berbahan plastik sehingga permiabel terhadap oksigen. ${ }^{7}$ Selain itu, pada saat proses fermentasi dan/atau penyimpanan, kultur starter St. thermophilus dan $L$. bulgaricus akan memproduksi asam-asam organik yang menyebabkan terjadinya penurunan $\mathrm{pH}$, sehingga dapat menurunkan viabilitas bakteri. ${ }^{11}$ Menurunnya jumlah bakteri Bifidobacterium juga akan menurunkan efek kesehatan yang seharusnya diperoleh saat mengonsumsinya.

Pada kedua kelompok subyek penelitian ini, asupan serat masih sangat rendah. Asupan diet dan gaya hidup akan sangat berpengaruh pada kondisi mikrobiota dalam usus orang dewasa. Diet seimbang, misalnya dengan mengonsumsi banyak serat sangat dianjurkan pada saat mengonsumsi yogurt karena serat dapat berfungsi sebagai prebiotik. Adanya prebiotik dapat membantu mengefektifkan kerja probiotik dengan cara menstabilkan dan melindungi sel bakteri probiotik ketika masuk dalam sistem pencernaan manusia. ${ }^{12}$

\section{SIMPULAN}

Tidak terdapat perbedaan yang signifikan pada nilai selisih glukosa darah puasa antara kelompok kontrol dengan kelompok perlakuan, namun penurunan nilai kelompok kontrol lebih besar dibandingkan penurunan nilai kelompok perlakuan $(p>0,05)$. Berdasarkan hasil penelitian ini, secara garis besar yogurt mampu dijadikan sebagai salah satu alternatif snack bagi penyandang diabetes mellitus tipe 2 karena efek penurunan glukosa darah puasa yang ditimbulkannya.

Peneliti merekomendasikan adanya penelitian lebih lanjut dengan masa intervensi yang diperpanjang agar penurunan nilai glukosa darah puasa lebih signifikan secara klinis. Selain itu, mempertimbangkan proses pembuatan yang lebih mudah, yogurt konvensional lebih dianjurkan karena kultur bakteri lebih mudah dikultivasi dan terbukti telah dapat menurunkan glukosa darah puasa.

\section{UCAPAN TERIMA KASIH}

Terimakasih ditujukan kepada semua pihak yang bersedia membantu terlaksananya penelitian ini, terutama kepada para subyek penelitian, CHR-Hansen Jakarta, CV. Violla Food Sleman, dan Laboratorium Klinik HiLab Kota Yogyakarta.

\section{DAFTAR PUSTAKA}

1. Gregg EW, Li Y, Wang J, Rios Burrows N, Ali MK, Rolka D, et al. Changes in Diabetes-Related Complications in the United States, 1990-2010. N Engl J Med [Internet]. 2014;370(16):1514-23. Available from: http://www.nejm.org/doi/10.1056/NEJMoa1310799

2. Paneni F, Beckman JA, Creager MA, Cosentino F. Diabetes and Vascular Disease: Pathophysiology, 
Clinical Consequences, and Medical Therapy: Part I. Eur Heart J. 2013;34(31):2436-46.

3. Rask-Madsen C, King GL. Vascular Complications of Diabetes: Mechanism of Injury and Protective Factors. Cell Metab J. 2014;17(1):20-33.

4. Al-Salami H, Butt G, Fawcett JP, Tucker IG, Golocorbin-Kon S, Mikov M. Probiotic Treatment Reduces Blood Glucose Levels and Increases Systemic Absorption of Gliclazide in Diabetes Rats. Eur J Drug Metab Pharmacokinet. 2008;33(2):1016.

5. Ejtahed HS, Mohtadi-Nia J, Homayouni-Rad A, Niafar M, Asghari-Jafarabadi M, Mofid V. Probiotic Yogurt Improves Antioxidant Status in Type 2 Diabetes Patients. Nutrition. 2012;28(5):539-43.

6. Yerlikaya O. Starter Cultures Used in Probiotic Dairy Product Preparation and Popular Probiotic Dairy Drinks. Food Sci Technol. 2014;34(June):221-9.

7. Tripathi MK, Giri SK. Probiotic Functional Foods: Survival of Probiotics during Processing and Storage. J Funct Foods. 2014;9:225-41.

8. Moreno-Indias I, Cardona F, Tinahones FJ, QueipoOrtuo MI. Impact of the Gut Microbiota on the
Development of Obesity and Type 2 Diabetes Mellitus. Front Microbiol. 2014;5(APR):1-10.

9. Linares DM, Gómez C, Renes E, Fresno JM, Tornadijo ME, Ross RP, et al. Lactic Acid Bacteria and Bifidobacteria with Potential to Design Natural Biofunctional Health-Promoting Dairy Foods. Front Microbiol. 2017;8(MAY):1-11.

10. Lecomte X, Gagnaire V, Lortal S, Dary A, Genay M. Streptococcus thermophilus, an Emerging and Promising Tool for Heterologous Expression: Advantages and Future Trends. Food Microbiol. 2016;53:2-9.

11. Rutella GS, Tagliazucchi D, Solieri L. Survival and Bioactivities of Selected Probiotic Lactobacilli in Yogurt Fermentation and Cold Storage: New Insights for Developing a Bifunctional Dairy Food. Food Microbiol [Internet]. 2016;60:54-61. Available from: http://dx.doi.org/10.1016/j.fm.2016.06.017

12. Ziarno M, Zareba D. Effects of Milk Components and Food Additives on Survival of Three Bifidobacteria Strains in Fermented Milk Under Simulated Gastrointestinal Tract Conditions. Microb Ecol Health Dis. 2015;26:27812. 